\title{
Glomerular nodules and long-spacing collagen in kidneys of patients with multiple myeloma
}

\author{
G. E. SCHUBERT ${ }^{1}$ AND A. ADAM \\ From the Institute of Pathology, University of Tübingen, Tübingen, West Germany
}

SYNOPSIS Light microscopic examination of the kidneys in 170 patients with multiple myeloma revealed three from patients without diabetes with glomerular nodules that were indistinguishable from those of diabetic glomerular sclerosis. Electron microscopic studies showed the nodules to be deposits of fine-grained material that corresponded to precipitations of protein but lacked the basement-membrane-like material characteristic of nodular glomerulosclerosis in diabetics. What is more, a unique collagen was observed in the marginal area of the nodules and in the periglomerular interstitium. The possible causes of the origin and distribution of this collagen not so far described in the human kidney are discussed.

In recent years, glomerular nodules which could not be differentiated by light microscopy from a nodular diabetic glomerular sclerosis have been observed in kidneys of patients with multiple myeloma who showed no clinical indications of diabetes mellitus. So far no suitable explanation for the pathogenesis and morphogenesis of these nodules has been given (Kenis, Cauchie, Potvliege, Smulders, Gompel, and Lambert, 1961; Kobernick and Whiteside, 1957; Martin, 1972; Olsen, 1972). We have recently seen three cases with these glomerular nodules and performed electron microscopic studies. We found that the ultrastructure of the mesangial nodules was different from the classical diabetic glomerulosclerosis. Furthermore, an extraordinary collagen was found which, to our knowledge, has not yet been described in the human kidney. We consider, therefore, a detailed description of these cases is warranted.

\section{Materials and Methods}

The kidneys from 170 patients with multiple myeloma were evaluated histologically. Nodular widenings of the glomerular mesangium, which strongly resembled those of diabetic glomerulosclerosis, were observed in three cases. Clinically,

'Please address correspondence to: Professor Dr G. E. Schubert, Institute of Pathology, University of Tübingen, Liebermeisterstr. 8, D 7400 Tübingen/Germany.

Received for publication 30 May 1974. however, diabetes mellitus could be ruled out in these patients, and the kidneys were subjected to further examination.

The renal tissue examined was secured by needle biopsy in case 1 and by necropsy eight and about 20 hours after death in cases 2 and 3 respectively. The light microscopic investigations were carried out on paraffin sections $8 \mu$ thick using the following stains: haematoxylin-eosin, Goldner-Trichrom, PAS, Elastica van Gieson, and Congo red according to Puchteler (1962). The tissue in the second and third cases was examined on methachrylate-embedded Movat-silvered semithin sections $0.5 \mu$ thick. Electron microscopic studies were performed on formol-fixed necropsy specimens, postfixed in cold $2 \% \mathrm{OsO}_{4}$ at a pH of 7.2. After embedding in methachrylate stain sections were stained with saturated uranyl acetate for 45 minutes; contrast staining followed in $0.4 \%$ lead acetate for two minutes.

\section{Results}

CASE 1

A 62-year-old man had an IGA plasmocytoma, the existence of which had been known for about a year. Because of renal unsufficiency with oliguria and the increase of the serum creatinine to $17 \mathrm{mg} \%$ and of the serum urea to $220 \mathrm{mg} \%$, a needle biopsy of the kidney was performed. The blood pressure at the time of the puncture was $160 / 80 \mathrm{~mm} \mathrm{Hg}$; the erythrocyte sedimentation rate was $75 / 127$.

Histologically, four of the seven glomeruli in the 
specimen were completely hyalinized. One glomerulus showed a slight, another a pronounced, nodular widening of the mesangium without any distinct increase in mesangial cells; the capillary walls were relatively delicate. The nodules took on a yellowishred colour with van Gieson stain, Congo red was negative and fibrin was not present. Atrophic tubules with isolated hyaline casts were present in the interstitium which was broadened by fibrosis and infiltrated by round cells. The interlobular arteries showed a significant hyalinosis of the intima and media.

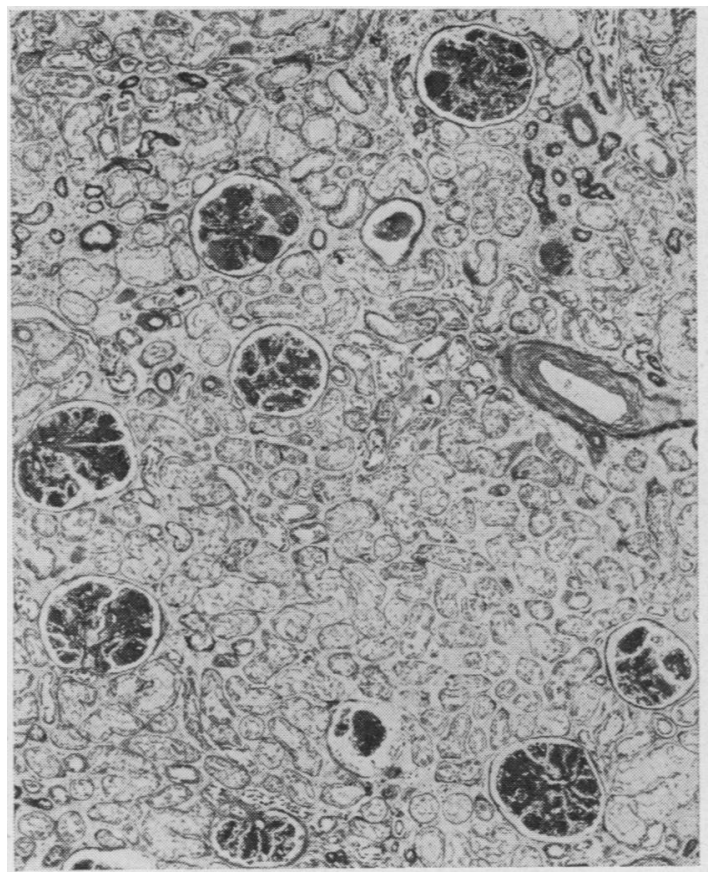

Fig 1 Light microscopic appearance $(25 \times)$ of a haematoxylin-and-eosin-stained kidney section from a 72-year-old non-diabetic man with Bence-Jones- $K$ myeloma (case 2). Note the numerous cell-deficient glomerular nodules.

\section{CASE 2}

A 72-year-old man, had a Bence-Jones-K-plasmacytoma which had been diagnosed one and a half years before death. The patient was oliguric during the last two weeks of life. Twelve days before death the serum creatinine rose to $6.3 \mathrm{mg} \%$ and the daily urine volume decreased to $400 \mathrm{ml}$. The blood pressure varied between $110 / 80$ and $150 / 80 \mathrm{~mm} \mathrm{Hg}$. There were no clinical indications of diabetes mellitus. The titre of insulin antibody in the serum (Dr Wehner, Tübingen) was not increased. The patient died of uraemia and a severe pancreatitis.
The smooth light medium-red surfaced kidneys together weighed $240 \mathrm{~g}$. The microscopic examination showed several fully hyalinized glomeruli in the subcapsular region. Atrophic tubules in this region, with conspicuously widened hyalinized basement membranes, were surrounded by fibrotic interstitium. In nearly all of the remaining glomeruli marked

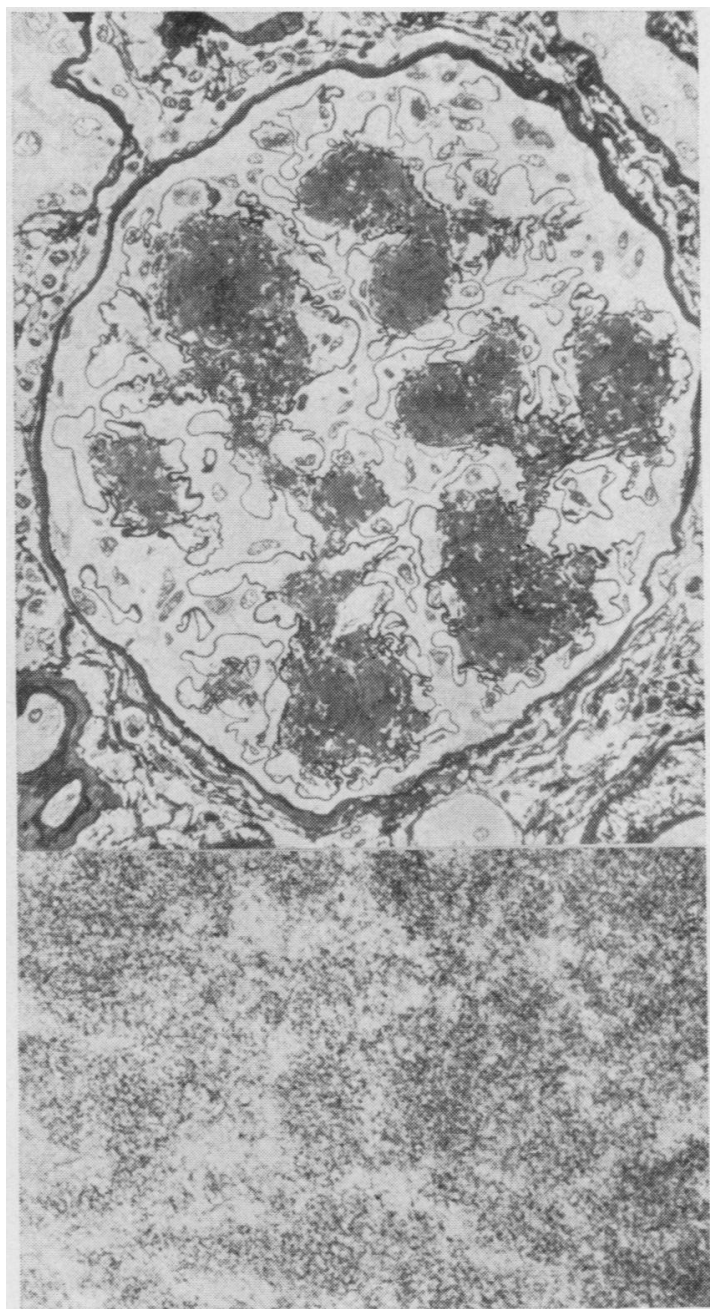

Fig 2a Semithin section of a glomerulus $(420 \times)$ from case 2. Granular or grainy-appearing masses are visible among the numerous cell-deficient nodular widenings of the mesangium. The basement membranes are inconspicuous.

Fig 2b Electron microscopic appearance $(77000 \times)$ o, a section of a nodular area from the mesangium in case 2. Note the fine granular deposits of the precipitated protein type. 
a

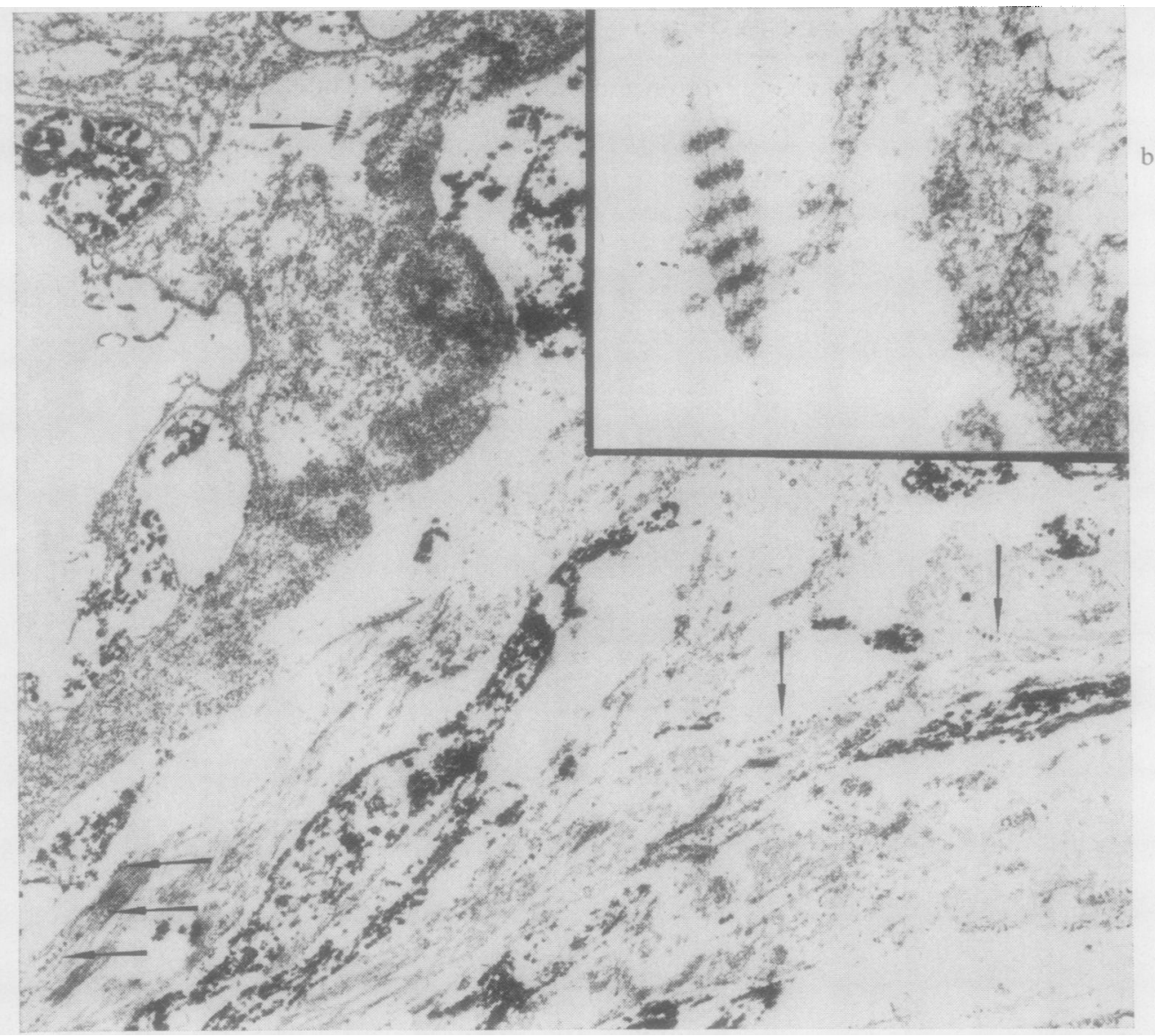

Fig 3a Electron micrograph $(14000 \times)$ of the 'banded bodies' or 'long-spacing collagen' in the region of the capillary wall (arrows) and in the periglomerular interstitium (arrows) in case 2.

Fig $3 \mathrm{~b}$ Enlarged sections from fig $3 a(77000 \times)$ showing the delicate longitudinal striations of the long-spacing collagen.

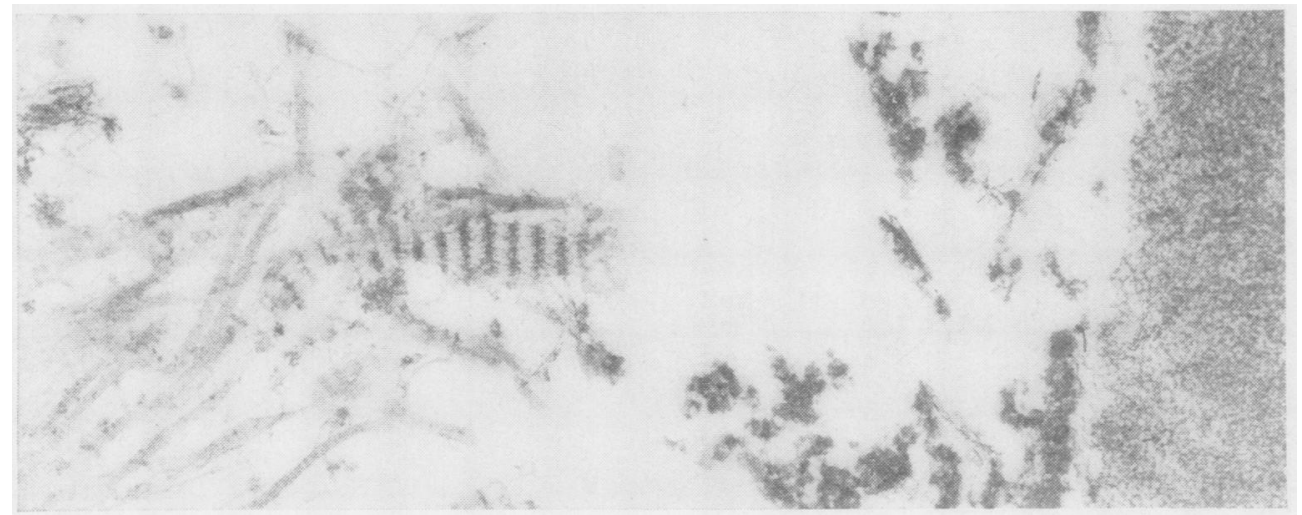

Fig 4 Long-spacing collagen ( $77000 \times$ ) attached or in close apposition to normal collagen fibres in the glomerular mesangium of case 2. The periodicity of the broad cross striations is $88 \mathrm{~nm}$. The lower margin is the hasement membrane. 
nodular widening of the mesangium was recognizable (fig 1), which was especially pronounced in non-atrophic areas of the inner and medial cortical zone. The cell-deficient, often cell-free, nodules were yellowish-red on van Gieson staining. They reacted negatively to amyloid staining as did the other regions. In semithin sections, the nodules appeared to have a fine granular or plaque-like structure (fig 2a). The basement membranes were not thickened, and subepithelial and subendothelial deposits could be found.

Electron microscopic examination showed these nodular mesangial thickenings to be fine granular structures of the precipitated protein type (fig $2 \mathrm{~b}$ ). Irregularly arranged precollagen and collagen fibres were observed in marginal sections of the nodules (fig 4). Spindle-shaped or long, ribbon-like structures with an average width at the widest part of $68.7 \pm 25.5 \mathrm{~nm}$ and a total length of $375.4 \pm$ $101.7 \mathrm{~nm}$ were seen in the immediate vicinity of the irregular fibres. These structures, marked by broad, dark, transverse striations with an average periodicity of $77.4 \pm 15.5 \mathrm{~nm}$, were seen under higher magnification to have delicate longitudinally orientated filaments (fig 3) and strongly resembled 'banded bodies' (Pillai, 1964) or 'curled collagen' (Garron, Feeney, Hogan, and McEwen, 1958). They occurred not only in the marginal areas but also occasionally within the fine granular glomerular nodules (fig 4), especially near the edges of mesangial cell nuclei. They were frequently observed in the interstitium surrounding the glomeruli and particularly often in the immediate vicinity of the basement membrane. Fibrin was not present in the glomeruli nor was amyloid found in the kidneys, although the necropsy showed an amyloidosis of the prostate.

\section{CASE 3}

In a 70-year-old man with gradually increasing renal insufficiency, the serum urea rose shortly before death to $365 \mathrm{mg} \%$. The haemoglobin had fallen to $55 \%$, the serum calcium to $3.2 \mathrm{~m}$-equiv $/ \mathrm{l}$, and the serum phosphorus had increased to $7.5 \mathrm{~m}$-equiv/l. The blood sedimentation rate was $123 / 143 \mathrm{~mm}$ and the globulin fraction in the serum increased to $20 \%$. The blood pressure was $215 / 110 \mathrm{~mm} \mathrm{Hg}$. The patient had a heavy proteinuria with a protein excretion of $10 \mathrm{~g} / 24 \mathrm{hr}$. A plasmacytoma was first diagnosed by sternal puncture only four weeks before death.

Histological examination of the enlarged, pale kidneys showed nodular widenings of the mesangium in practically all glomeruli. Under the light microscope these widenings appeared as fairly homogeneous deposits (fig 5a) between which lay several mesangial cells. The interstitium was slightly

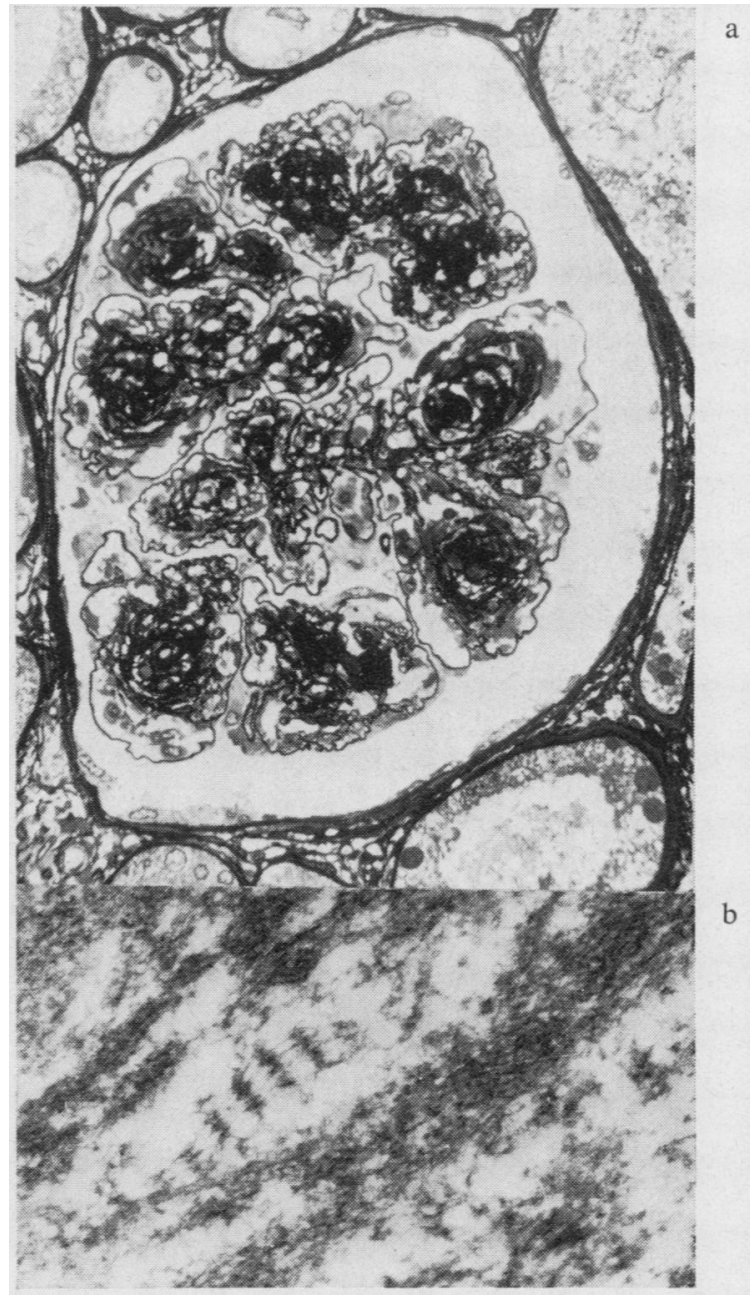

Fig 5a Semithin section $(340 \times)$ of the kidney from case 3, a 70-year-old non-diabetic man with plasmacytoma. Numerous nodules in all glomeruli and their thin basement membranes are apparent.

Fig $5 \mathrm{~b}$ Section of a nodular area $(77000 \times)$ from the mesangium in case 3. Banded bodies are recognizable among granular deposits of the precipitated protein type. The periodicity of the broad cross striations is $78 \mathrm{~nm}$.

fibrotic; the renal tubules were wide. Under the electron microscope the glomerular deposits in the widened mesangium proved to be of the protein precipitate type. Embedded in these masses were numerous long, ribbon-like structures (fig $5 b$ ), which strongly resembled those of case 2 . The periodicity of the broad, dark transverse striations was, on average, $78 \cdot 0 \mathrm{~nm}$. Often these structures were found 
in the vicinity of an apparently normal basement membrane or on the surface of mesangial cells. In addition, isolated collagen fibres were seen in the region of the mesangium.

\section{Discussion}

Examination of the kidneys from patients with multiple myeloma has failed to demonstrate characteristic changes in the glomeruli that can account for the frequent occurrence of renal insufficiency associated with this illness (Boulet, Mirouze, Pages, Barjon, Fabre, and Jaffiol, 1962; Hamburger, Richet, Crosnier, and Antoine, 1966; Kenis et al, 1966; Reubi, 1970; Schubert, 1974). The repeatedly described thickenings of the basement membrane, the increases in the numbers of epithelial, endothelial, and mesangial cells, as well as subepithelial deposits (Abrahams, Pirani, and Pollak, 1966; Costanza and Smoller, 1963; Fries, Bansilion, Brunat, Molinie, and Traeger, 1967; Kobernick and Whiteside, 1957; Rosen, Cortell, Adner, Papadopoulos, and Barry, 1967), are, according to Fisher, Perez-Stable, and Zawadzki (1964), more likely to be the result of an altered protein supply than the cause of renal disturbances. Widenings of the mesangium (Allen, 1962; Fisher et al, 1964) also cannot account for all cases of renal disturbances in patients with multiple myeloma and renal insufficiency, since Wehner, Feurer, and Wehner (1971) by exact measurements found decreased mesangial areas in some cases.

Our findings agree with reports of nodular widenings of the mesangium in some patients with plasmacytoma (Kobernick and Whiteside, 1957; Kenis et al, 1961; Martin, 1972; Olsen, 1972). The kidney morphology in these patients could not be differentiated from a diabetic glomerulosclerosis, even though there were no clinical signs of diabetes mellitus. Olsen (1972) suggested that the nodular widenings might be produced by abnormal mesangial deposits such as immunoproteins that provoke an increased synthesis and/or reduced catabolism of basement membrane-like substance. However, deposits of basement membrane-like material typical for long-term diabetic patients with nodular glomerulosclerosis were not apparent in the kidneys of our myeloma patients. Consequently, we were unable to verify Olsen's theory by electron microscopic examination of the glomerular nodules. Nevertheless, our findings show that the fine granular deposits in the mesangium correspond to protein precipitates which, according to Olsen, could precede the increase of basement membrane-like substance in this region. Amyloid deposits (Teilum and Lindahl, 1954; Heptinstall and Joekes, 1960; Olsen, 1972; Lendrum, Slidders, and Fraser, 1972) could neither be demonstrated by light nor by electron microscopy in our cases. Thus, although we have not completely clarified the nature of these nodules of plasmacytoma, our electron microscopic results point strongly toward a structure consisting of protein deposits and a scanty collagen fibre synthesis in the marginal sections of the glomerulus.

The kidneys of our patients examined by electron microscopy showed longish, frequently spindleshaped bodies with coarse cross striations, which strongly resemble the 'banded bodies' of Pillai (1964), the 'curly collagen' of Garron et al (1958), and the 'long spacing collagen' which Luse, Zopf, and Cox (1963) could reconstitute in vitro. To the best of our knowledge, these structures have not been previously described in the human kidney. On the other hand, this type of collagen has been described, for example, in the walls of cerebral vessels in old age (Schlote, 1966); in accoustic neurinomas and peripheral Schwannomas, where this structure was found to be absolutely diagnostic of these tumours (Raimondi, Mullan, and Evans, 1962; Luse, 1960); in other brain tumours (Ramsey, 1964); in Meissner's tactile corpuscles of the human finger (Cauna and Ross, 1960); within degenerating sensory cells of the human membranous labyrinth in Ménière's disease (Friedman, Cawthorne, McClay, and Bird, 1963); in human nodes (Luse et al, 1963) in Descemet's membrane of man and several an: mals (Feeney et al, 1961; Jakus, 1962; Van der Zypen, 1971); in retinal arterioles (Gärtner, 1966); around capillaries in the subcommissural organ of the brain of rats (Wetzstein, Schwink, and Stranka, 1963; Naumann and Wolfe, 1963); in the perineurium of tibial nerves of rats after constriction (Pillai, 1964); and in the region of the iridocorneal angle of the eye in patients with clinically manifest or latent systemic disease of the connective tissue (Rohen, 1962).

Information is still too incomplete to warrant any definite conclusions regarding the cause of the origin and distribution of this particular collagen in the human kidney. We presume that changes in the local milieu favour its synthesis, since the dependence of the collagen macromolecule (tropocollagen) aggregation on environmental conditions is well known. Factors such as the amount and kind of salt, $\mathrm{pH}$, temperature, and the concentration of collagen determine the formation of different aggregates with different band patterns. It is interesting to note that Pappas (1960) produced collagen with a periodicity of $120 \mathrm{~nm}$ amid normal filaments by adding chondroitin sulphate to the medium in tissue cultures of fibroblasts. The lower periodicity of the 'banded bodies' or 'long-spacing collagen' in our cases could be due to the existence 
of unique local conditions prevailing in their kidneys. The spatial relationships between the glomerular nodules, the basement membranes, and the 'banded bodies' is consistent with this notion. In subsequent investigations it will be necessary to examine whether particularly favourable conditions occur for the synthesis of this collagen in kidneys of patients with plasmacytoma.

This project was supported by the Deutsche Forschungsgemeinschaft. We are grateful to Professor W. Schlote, head of the Department for Submicroscopic Pathology and Cytopathology, University of Tübingen, for advice and help.

We wish to thank Professor A. Bohle for his permission to include case 3 in our report.

\section{References}

Abrahams, C., Pirani, C. L., and Pollak, V. E. (1966). Ultrastructure of the kidney in a patient with multiple myeloma. J. Path. Bact., 92, 220-225.

Allen, A. C. (1962). The Kidney, p. 240. 2nd ed., Grune and Stratton, New York.

Boulet, P., Mirouze, J., Pages, A., Barjon, P., Fabre, S., Jaffiol, C. (1962). Ponction-biopsie rénale et néphropathie Kahlériénne J. Urol. Néphrol., 68, 89-98.

Costanza, D. J., and Smoller, M. (1963). Multiple myeloma with the Fanconi syndrome: study of a case, with electron microscopy of the kidney. Amer. J. Med., 34, 125-133.

Feeney, M. L., and Garron, K. L. (1961). Descamet's membrane in the human peripheral cornea: a study by light and electron microscopy. In The Structure of the Eye, edited by G. K. Smelser, p. 367-280. Academic Press, New York.

Fisher, E. R., Perez-Stable, E., and Zawadzki, Z. A. (1964). Ultrastructural renal changes in multiple myeloma with comments relative to the mechanism of proteinuria. Lab. Invest., 13, 1561-1574.

Friedman, I., Cawthorne, T., McLay, K., and Bird, E. S. (1963). Electron microscopic observations on the human membranous labyrinth with particular reference to Ménière's disease. $J$. Ultrastruct. Res., 9, 123-138.

Fries, D., Banssillon, V., Brunat, N., Molinie, C., and Traeger, J. (1967). Ultrastructure des lésions glomérularies dans un cas de myélome avec syndrome néphrotique. J. Urol. Néphrol., 73, 839-850.

Garron, L. K., and Feeney, M. L. (1959). Electron microscopic studies of the human eye. II. Study of the trabeculae by light and electron microscopy. Arch. Ophthal., 62, 966-973.

Garron, L. K., Feeney, M. L., Hogan, M. J., and McEwen, W. K. (1958). Electron microscopic studies of the human eye. I. Preliminary investigations of trabeculas. Amer. J. Ophthal., 46, 27-35.

Gärtner, J. (1966). 'Long-spacing' Kollagen in der Wand einer Netzhautarteriole. Path, et Microbiol., 29, 55-62.

Hamburger, J., Richet, G., Crosnier, J., and Antoine, B. (1966). Néphrologie. Flammarion, Paris.

Heptinstall, R. H., and Joekes, A. M. (1960). Renal amyloid: a report on eleven cases proven by renal biopsy. Ann. rheum. Dis., 19, 126-134.

Jakus, M. A. (1962). Further observations on the fine structure of the cornea. Invest. Ophthal., 1, 202-225.
Kenis, Y., Cauchie, C. Potvliege, P. Smulders, J., Gompel, C., and Lambert, P. P. (1961). Les manifestations renales du myelome. Acta clin. belg., 16, 541-574.

Kobernick, S. D., and Whiteside, J. H. (1957). Renal glomeruli in multiple myeloma. Lab. Invest., 6, 478-485.

Lendrum, A. C., Slidders, W. and Fraser, D. S. (1972). Renal hyalin: a study of amyloidosis and diabetic fibrinous vasculosis with new staining methods. J. clin. Path., 25, 373-396.

Luse, S. A. (1960). Electron microscopic studies of brain tumours. Neurology (Minneap.), 10, 881-905.

Luse, S. A., Zopf, D., and Cox, J. W. (1963). An electron microscopic study of in vitro and in vivo long-spacing collagen. (Abstr.) Anat. Rec., 145, 254-255.

Martin, H. (1972). Die Plasmozytomniere: vergleichende histologische und klinische Untersuchungen. Zbl. allg. Path., 115, 307-321.

Naumann, R. A., and Wolfe, D. E. (1963). A striated intercellular material in rat brain. Nature (Lond.), 198, 701-703.

Olsen, S. (1972). Mesangial thickening and nodular glomerular sclerosis in diabetes mellitus and other diseases. Acta path. microbiol. scand., Sect. A, Suppl. 233, 203-216.

Pappas, G. D. (1960). In Glaucoma: Transactions of the 4th Conference, New Jersey, 1959, edited by F. W. Newell, p. 54. Josiah Macy, Jr. Foundation, New York.

Pillai, P. A. (1964). A banded structure in the connective tissue of nerve. J. Ultrastruct. Res., 11, 455-468.

Puchtler, H., Sweat, F., and Levine, M. (1962). On the binding of Congo red by amyloid. J. Histochem. Cytochem., 10, 355.

Raimondi, A. J., Mullan, S., and Evans, J. P. (1962). Human brain tumours: an electron-microscopic study. J. Neurosurg., 19, 731-753.

Reubi, F. (1970). Nierenkrankheiten, 2nd ed. Huber, Berne and Stuttgart.

Rohen, J. W. (1962). Uber das Ligamentum pectinatum der Primaten. Z. Zellforsch., 58, 403-421.

Rohen, J. W. (1963). Experimental studies on the trabecular meshwork in primates. Arch. Ophthal., 69, 335-349.

Rosen, S., Cortell, S., Adner, M. M. Papadopoulos, N. M., and Barry, K. G. (1967). Multiple myeloma and the nephrotic syndrome: a biochemical and morphologic study. Amer. J. clin. Path., 47, 567-579.

Schlote, W. (1966). Polarisationsoptische und elektronenmikroskopische Beobachtungen bei 'drüsiger' Degeneration der Hirnrindengefä $\beta$ e im Senium. In Proceedings of the 5th International Congress on Neuropathology (Int. Congr. Ser., No. 100) edited by F. Lüthy and A. Bischoff, pp. 490-494. Eccerpta Medica Foundation, Amsterdam.

Schubert, G. E. (1974). Die Plasmocytomniere. I. Häufigkeit pathologisch-anatomischer Vernäderungen. Klin. Wschr. 52, 763-770.

Schubert, G. E. (1974). Die Plasmocytomniere. II. Vergleich klinischer und pathologische-anatomischer Befunde unter besonderer Berücksichtitgung des akuten Nierenversagens. Klin. Wschr. 52, 771-780.

Speakman, J. S. (1962). Nodular dystrophy of the trabecular meshwork. Brit. J. Ophthal., 46, 31-39.

Teilum, G., and Lindahl, A. (1954). Frequency and significance of amyloid changes in rheumatoid arthritis. Acta med. scand., 149, 449-455.

Wehner, H., Feurer, F., and Wehner, I. (1971). Histometrical glomerular studies on the kidneys in multiple myeloma and in acute membranous glomerulonephritis (lipoid nephrosis). Path. europ. 6, 422-432.

Wetzstein, R., Schwink, A., and Stanka, P. (1963). Die periodisch strukturierten Körper im Subcommissuralorgan der Ratte. Z. Zellforsch., 61, 493-523.

Zypen, van der, E. (1971). Vergleichende licht- und elektronenmikroskopische Untersuchungen uber die morphologischen Grundlagen der Liquor- und Kammerwasserzirkulation. In Altern und Entwicklung, Bd. 2, edited by H. Bredt and J. W. Rohen. Schattauer, Stuttgart and New York. 